\title{
Blast from the past: a novel complication of bronchopulmonary dysplasia
}

\author{
Tyler Church, ${ }^{1}$ Kyle Keinath, ${ }^{1}$ Whittney Warren, ${ }^{2}$ John Sherner ${ }^{2}$
}

'Internal Medicine, Walter Reed National Military Medical Center, Bethesda, Maryland, USA

2Department of Pulmonology/ Critical Care, Walter Reed National Military Medical Center, Bethesda, Maryland, USA

\section{Correspondence to Dr Kyle Keinath, kyleke@pcom.edu}

Accepted 9 July 2018

\section{DESCRIPTION}

A 43-year-old Caucasian woman presented to her primary care physician for a retirement physical exam. She endorsed mild dyspnoea on exertion, but denied chest pain, cough or shortness of breath at rest. On physical exam, lungs were clear bilaterally with good air movement in all fields. Chest radiograph was normal except for a $6 \mathrm{~mm}$ nodular density noted in the right lower lobe. A non-contrast CT scan of the chest was performed revealing a $2 \mathrm{~mm}$ calcified granuloma. In addition, there were global, mild and uniform paraseptal emphysematous changes throughout the pleural surfaces of the lungs and the fissures (figures 1 and 2). Pulmonary work-up including spirometry, carbon monoxide diffusing capacity and testing for alpha-1 antitrypsin deficiency was normal. Further investigation revealed a history of premature birth, supported with mechanical ventilation $(\mathrm{MV})$. We attributed her radiographic findings and symptoms to sequelae of bronchopulmonary dysplasia (BPD).

$\mathrm{BPD}$ is a pulmonary complication of premature birth. ${ }^{1}$ BPD occurs in premature infants experiencing respiratory distress syndrome (RDS) treated with MV, resulting in an inflammatory condition characterised by diverse radiographic findings and histologically by fibrosis and smooth muscle hypertrophy in the pulmonary tissues. ${ }^{12}$ The long-term sequelae of BPD are heterogeneous and depend on the initial degree of insult. MV of the premature infant in the setting of RDS is the predominant risk factor. Mild to moderate BPD may have no long-term effects with normal to only mildly obstructed spirometry; these patients typically go on to have normal chest radiographs by

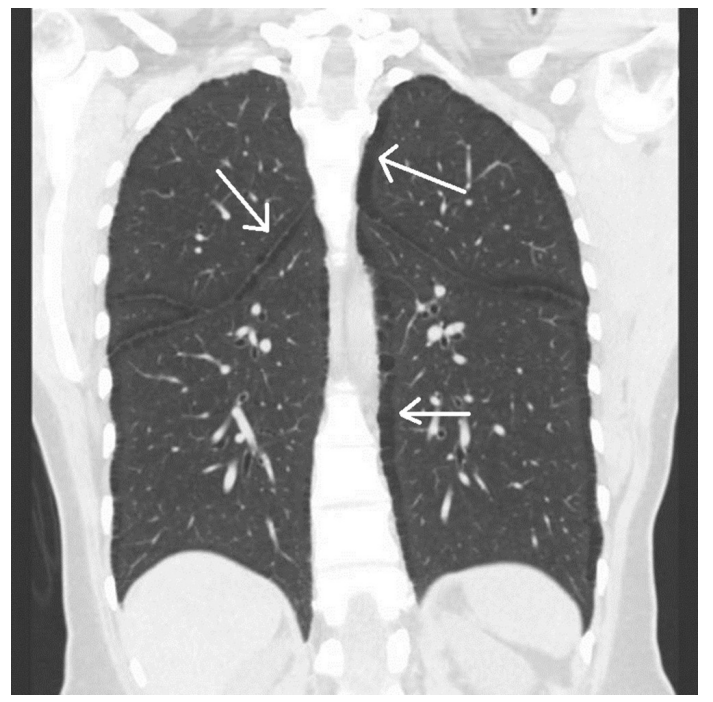

Figure 1 Coronal non-contrast enhanced CT of the chest: clear findings of diffuse, paraseptal emphysematous changes, as indicated by the arrows.

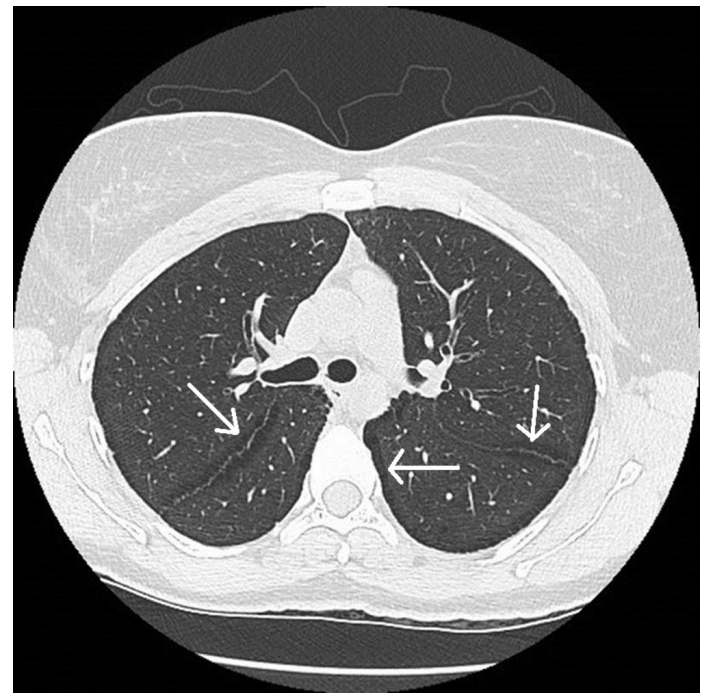

Figure 2 Cross-sectional non-contrast enhanced CT of the chest: demonstrating diffuse, paraseptal emphysematous changes, as indicated by the arrows.

adolescence. ${ }^{2}$ More severe cases may demonstrate bronchial wall thickening, air trapping, lung cysts, linear interstitial opacities and emphysema. ${ }^{1}$ Case series suggest infants with BPD have more frequent airway hyper-reactivity in adulthood and may have increased susceptibility to respiratory infections. ${ }^{2}$

Our patient presented with minimal symptoms, a history of MV during premature infancy and a novel, bilateral paraseptal emphysematous pattern without other underlying aetiology suggesting BPD as the cause. Prevention in premature infants is key to management of this disease and centres on minimising airway pressures during $\mathrm{MV}$, antenatal glucocorticoids and exogenous surfactant therapy. The sequela of BPD infrequently persists into adulthood. We postulate that the diffuse and symmetric paraseptal emphysema in this adult patient with no other pulmonary risk factors is a previously undescribed manifestation of BPD as a premature infant.

Learning points

- Bronchopulmonary dysplasia (BPD) is a pulmonary complication of premature birth. BPD occurs in premature infants treated with mechanical ventilation, resulting in inflammation leading to fibrosis and smooth muscle hypertrophy.

- Mild to moderate BPD may have no long-term effects with normal to only mildly obstructed spirometry; these patients typically go on to have normal chest radiographs by adolescence. 
Contributors All of the authors had direct role in the care of the presented patient. The manuscript was written by TC and KK. Mentorship and editing was performed by WW and JS.

Funding The authors have not declared a specific grant for this research from any funding agency in the public, commercial or not-for-profit sectors.

Competing interests None declared.

Patient consent Obtained.
Provenance and peer review Not commissioned; externally peer reviewed.

\section{REFERENCES}

1 Howling SJ, Northway WH, Hansell DM, et al. Pulmonary sequelae of bronchopulmonary dysplasia survivors: high-resolution CT findings. AJR Am J Roentgenol 2000;174:1323-6.

2 Northway WH, Moss RB, Carlisle KB, et al. Late pulmonary sequelae of bronchopulmonary dysplasia. N Engl J Med 1990;323:1793-9.

Copyright 2018 BMJ Publishing Group. All rights reserved. For permission to reuse any of this content visit

http://group.bmj.com/group/rights-licensing/permissions.

BMJ Case Report Fellows may re-use this article for personal use and teaching without any further permission.

Become a Fellow of BMJ Case Reports today and you can:

- Submit as many cases as you like

- Enjoy fast sympathetic peer review and rapid publication of accepted articles

Access all the published articles

Re-use any of the published material for personal use and teaching without further permission

For information on Institutional Fellowships contact consortiasales@bmjgroup.com

Visit casereports.bmi.com for more articles like this and to become a Fellow 